\title{
Hubungan Derajat Merokok dengan Gejala Gangguan Sistem Pernapasan pada Pegawai Universitas Islam Bandung
}

\author{
Aliya Salsabila*, Yuniarti \\ Prodi Pendidikan Kedokteran, Fakultas Kedokteran, Universitas Islam \\ Bandung, Indonesia. \\ *alyslsbl@gmail.com, candytone26@gmail.com
}

\begin{abstract}
Smoking is a major risk factor for respiratory disease that can be detected early by knowing the symptoms of respiratory disorders. Smoking has become a habit for many Indonesians, including some employees of Bandung Islamic University (Unisba). This study aimed to analyse the relationship between smoking degree and respiratory symptoms in Unisba employees. The research method was an analytic study and the research design was cross sectional with a purposive sampling technique. Respondents were 77 Unisba employees who were divided into two groups, namely 33 risk factor groups (active smokers) and 44 control groups (non-smokers) for comparison. The smoking degree was assessed using a form based on the Brinkman index (the average number of cigarettes smoked per day in sticks multiplied by the length of smoking in years) which grouped into mild, moderate, and heavy smoker. Respiratory symptoms were assessed using a standard COPD Assessment Test (CAT) questionnaire which categorized into normal (asymptomatic) and abnormal (mild, moderate, severe, and very severe symptoms). Research data were analysed using fisher's exact test as an alternative because the chi square test requirements were not met. The analysis results showed $\mathrm{p}$ value $=0.921(\mathrm{p}>0.05)$, meaning that the results were not statistically significant. The conclusion of the study is that there is no relationship between the smoking degree and respiratory symptoms in Unisba employees. Factors that can influence are passive smoking, smoking history, age, history of respiratory disease, nutritional status, exercise habits, and exposure to dust.
\end{abstract}

Keywords: Brinkman index, CAT, Respiratory symptoms, Smoking.

Abstrak. Merokok merupakan faktor risiko utama dari penyakit pernapasan yang dapat dideteksi secara dini dengan mengetahui gejala gangguan sistem pernapasan. Merokok telah menjadi kebiasaan bagi banyak masyarakat Indonesia, termasuk sebagian pegawai Universitas Islam Bandung (Unisba). Penelitian ini bertujuan untuk menganalisis hubungan derajat merokok dengan gejala gangguan sistem pernapasan pada pegawai Unisba. Metode penelitian merupakan studi analitik dan rancangan pendekatan cross sectional dengan teknik pemilihan sampel purposive sampling. Responden sebanyak 77 pegawai Unisba yang terbagi menjadi dua kelompok, yaitu 33 kelompok faktor risiko (perokok aktif) dan 44 kelompok kontrol (bukan perokok) sebagai pembanding. Derajat merokok dinilai menggunakan formulir isian berdasarkan indeks Brinkman (jumlah rata-rata rokok yang dihisap per hari dalam satuan batang dikalikan dengan lama merokok dalam satuan tahun) yang dikelompokkan menjadi perokok ringan, sedang, dan berat. Gejala gangguan sistem pernapasan dinilai menggunakan kuesioner baku COPD Assessment Test (CAT) yang dikelompokkan menjadi kategori normal (tidak bergejala) dan abnormal (bergejala ringan, sedang, berat, dan sangat berat). Data penelitian dianalisis menggunakan uji fisher's exact sebagai alternatif karena syarat uji chi square tidak terpenuhi. Hasil uji analisis menunjukkan nilai $\mathrm{p}=0,921(\mathrm{p}>0,05)$, artinya hasil tidak signifikan secara statistik. Simpulan penelitian adalah tidak terdapat hubungan antara derajat merokok dengan gejala gangguan sistem pernapasan pada pegawai Unisba. Faktor yang dapat memengaruhi adalah merokok pasif, riwayat merokok, usia, riwayat penyakit pernapasan, status gizi, kebiasaan olahraga, dan paparan debu.

Kata Kunci: CAT, Gejala pernapasan, Indeks Brinkman, Merokok. 


\section{A. Pendahuluan}

Merokok merupakan bentuk utama dari penggunaan tembakau yang berperan sebagai faktor risiko berbagai penyakit kronis. Merokok menjadi penyebab utama dari kematian yang dapat dicegah di seluruh dunia. World Health Organization (WHO) telah memprediksi bahwa terdapat sekitar 6 juta kematian per tahun yang dihubungkan dengan rokok dan akan terus meningkat hingga lebih dari 8 juta kematian pada tahun 2030. Saat ini diperkirakan jumlah perokok di dunia berjumlah 1,3 miliar orang. Jumlah perokok laki-laki lebih banyak dibandingkan perempuan. Setengah perokok di dunia berusia produktif dan dapat mengalami penurunan usia hidup hingga 20 sampai 25 tahun karena merokok. Jumlah perokok di Indonesia menempati urutan ketiga terbesar di dunia setelah Tiongkok dan India.

Berdasarkan data dari Riset Kesehatan Dasar (Riskesdas) tahun 2018, proporsi penduduk berusia $\geq 10$ tahun yang merokok di Indonesia adalah sebesar $24,3 \%$ untuk perokok setiap hari dan 4,6\% untuk perokok kadang-kadang (proporsi total 28,9\%). Jawa Barat merupakan provinsi dengan prevalensi total tertinggi, yaitu 32\% dengan rincian $27,1 \%$ perokok setiap hari dan 4,9\% perokok kadang-kadang. Proporsi perokok yang bekerja di Jawa Barat lebih banyak dibanding dengan proporsi perokok yang tidak bekerja dan masih sekolah. Perbedaan proporsi perokok laki-laki di Jawa Barat lebih banyak dibanding dengan proporsi perokok perempuan. Kebiasaan merokok yang tinggi berkaitan erat dengan peningkatan kejadian penyakit pernapasan pada perokok.

Rokok merupakan salah satu faktor risiko yang paling berperan dalam meningkatkan angka kesakitan akibat penyakit pernapasan. Jenis penyakit pernapasan terbanyak akibat konsumsi tembakau merupakan penyakit paru obstruktif kronis (PPOK). Asap rokok yang bersifat iritan akan merusak jaringan ikat di parenkim paru dan merangsang sekresi mukus berlebih sehingga terjadi emfisema dan obstruksi saluran napas. Zat iritan pada rokok dapat mengakibatkan iritasi saluran pernapasan dan reaksi inflamasi yang dapat memicu stres oksidatif dalam patogenesis PPOK. Oleh sebab itu, pencegahan merokok menjadi prioritas untuk mengurangi angka kejadian penyakit pernapasan.

Penyakit pernapasan dapat dideteksi secara dini dengan mengetahui gejala-gejala pernapasan seperti batuk, batuk berdahak, bersin, pilek, iritasi tenggorokan, sesak napas, nyeri dada, dan mengi. Risiko gangguan pernapasan dapat dialami oleh perokok terutama perokok aktif sehingga menjadi ancaman gangguan kesehatan bagi masyarakat.

Beberapa peraturan telah dikeluarkan oleh pemerintahan Indonesia sebagai upaya untuk mengurangi risiko ancaman gangguan kesehatan yang disebabkan oleh rokok. Salah satu upaya yang dilakukan adalah dengan pemberlakuan Kawasan Tanpa Rokok (KTR) di fasilitas pelayanan kesehatan, tempat proses belajar mengajar, tempat kerja, dan tempat ibadah. Universitas Islam Bandung (Unisba) sebagai salah satu kampus swasta Islam terbesar di Bandung telah turut menerapkan KTR sejak tahun 2018.

Penerapan KTR di Unisba diwujudkan sebagai Kampus Bebas Asap Rokok. Program ini bertujuan untuk memperbaiki perilaku masyarakat kampus menjadi lebih sehat, mewujudkan kampus berwawasan lingkungan (eco campus), meningkatkan kualitas udara yang bersih dan bebas asap rokok, serta menerapkan nilai-nilai Islam di lingkungan kampus yang selaras dengan Q.S. Al-Baqarah ayat 195 yang artinya: "Dan belanjakanlah (harta bendamu) di jalan Allah, dan janganlah kamu menjatuhkan dirimu sendiri ke dalam kebinasaan, dan berbuat baiklah, karena sesungguhnya Allah menyukai orang-orang yang berbuat baik." Penetapan kebijakan Kampus Bebas Asap Rokok yang diselenggarakan di lingkungan Unisba tidak menjamin masyarakat Unisba tidak merokok di luar lingkungan kampus.

Berdasarkan latar belakang penelitian yang telah diuraikan, rumusan masalah penelitian ini adalah sebagai berikut: "Bagaimana hubungan derajat merokok dengan gejala gangguan sistem pernapasan pada pegawai Unisba?" Tujuan penelitian ini adalah untuk meneliti hubungan derajat merokok dengan gejala gangguan sistem pernapasan pada pegawai Unisba dalam upaya meningkatkan kesadaran tentang bahaya rokok serta deteksi dini gejala gangguan sistem pernapasan pada pegawai Unisba. 


\section{B. Metodologi Penelitian}

Penelitian ini merupakan penelitian analitik dengan pendekatan cross sectional. Subjek penelitian terbagi menjadi dua kelompok, yaitu kelompok faktor risiko (perokok aktif) dan kelompok kontrol (bukan perokok) sebagai pembanding. Teknik pemilihan sampel yang digunakan adalah teknik purposive sampling berdasarkan kriteria inklusi dan eksklusi.

Kriteria inklusi meliputi tenaga kependidikan Universitas Islam Bandung tahun 2020/2021 berjenis kelamin laki-laki, bersedia menjadi subjek penelitian, punya akses internet dan dapat menggunakan google form, serta perokok aktif (merokok setiap hari dalam jangka waktu minimal enam bulan selama hidup dan masih merokok pada saat dilakukan penelitian) untuk kelompok faktor risiko dan bukan perokok untuk kelompok kontrol. Kriteria eksklusi meliputi subjek penelitian yang diketahui mengidap penyakit jantung, GERD (penyakit asam lambung), gagal ginjal, anemia, obesitas, gangguan kecemasan, dan penyakit pernapasan (pneumonia, tuberkulosis, asma, dan atelektasi) berdasarkan diagnosis dokter. Berdasarkan kriteria inklusi dan eksklusi, didapatkan responden penelitian sebanyak 77 pegawai Unisba dengan rincian kelompok kontrol sebanyak 44 orang yang tidak merokok dan kelompok faktor risiko sebanyak 33 orang yang merokok.

Penelitian ini terdiri dari dua variabel, yaitu derajat merokok sebagai variabel bebas dan gejala gangguan sistem pernapasan sebagai variabel terikat. Penilaian derajat merokok menggunakan formulir isian berdasarkan indeks Brinkman (jumlah rata-rata rokok yang dihisap per hari dalam satuan batang dikalikan dengan lama merokok dalam satuan tahun) yang dikelompokkan menjadi perokok ringan, perokok sedang, dan perokok berat. Gejala gangguan sistem pernapasan dinilai menggunakan kuesioner baku COPD Assessment Test (CAT) yang dikelompokkan menjadi kategori normal (tidak bergejala) dan abnormal (bergejala ringan, sedang, berat, dan sangat berat). Data penelitian dianalisis menggunakan uji fisher's exact sebagai alternatif karena syarat uji chi square, yaitu tidak ada sel yang bernilai 0 dan sel dengan nilai $<5$ tidak lebih dari $20 \%$, tidak terpenuhi.

Pengambilan kesimpulan pada uji statistik dilakukan dengan melihat nilai p. Nilai $\mathrm{p}$ yang lebih kecil dari $0,05(\mathrm{p}<0,05)$ dapat diartikan bahwa terdapat hubungan yang signifikan secara statistik antara derajat merokok dan gejala gangguan sistem pernapasan pada pegawai Unisba. Nilai $p$ yang lebih besar dari $0,05(\mathrm{p}>0,05)$ dapat diartikan bahwa tidak terdapat hubungan yang signifikan secara statistik antara derajat merokok dan gejala gangguan sistem pernapasan pada pegawai Unisba.

\section{Hasil Penelitian dan Pembahasan}

Karakteristik kebiasaan merokok responden meliputi jumlah rata-rata rokok yang dihisap (batang per hari) dan lama merokok (dalam satuan tahun) pegawai Unisba. Hasil distribusi gambaran karakteristik karakteristik kebiasaan merokok responden ditampilkan pada tabel 1.

Tabel 1. Gambaran Karakteristik Kebiasaan Merokok Pegawai Unisba

\begin{tabular}{|l|c|c|}
\hline \multicolumn{1}{|c|}{ Karakteristik } & Jumlah (n) & Persentase (\%) \\
\hline Jumlah rokok (batang/hari) & 20 & \\
$1-10$ & 11 & $61 \%$ \\
$11-20$ & 2 & $33 \%$ \\
$>20$ & & $6 \%$ \\
\hline Lama merokok (tahun) & 5 & $15 \%$ \\
$1-9$ & 17 & $52 \%$ \\
$10-19$ & 4 & $12 \%$ \\
$20-29$ & 7 & $21 \%$ \\
$\geq 30$ & 33 & $100 \%$ \\
\hline Total & &
\end{tabular}

Sumber: Data Penelitian yang Sudah Diolah, 2020. 
Distribusi frekuensi jumlah rokok yang dihisap mayoritas pegawai Unisba per har pada waktu penelitian dilakukan sama dengan distribusi frekuensi jumlah rokok yang dihisap mayoritas karyawan Unisba per hari pada tahun 2017 dalam penelitian Putra dkk., yaitu 1-10 batang.

Berdasarkan hasil penelitian, sebagian besar pegawai Unisba telah merokok selama 1019 tahun. Lama merokok pegawai Unisba lebih singkat jika dibandingkan dengan responden pada penelitian Liu dkk. Yang mayoritas telah merokok selama $\geq 30$ tahun.

Kebiasaan merokok pada pegawai Unisba menunjukkan bahwa terdapat potensi adiksi terhadap nikotin. Nikotin merupakan salah satu zat berbahaya yang terkandung dalam rokok. Nikotin dapat memicu kanker paru, memengaruhi sirkulasi darah, persarafan, serta bersifat adiktif. Efek adiktif yang dihasilkan nikotin akan memberikan pengaruh psikologis, seperti rasa senang dan nikmat ketika seseorang merokok. Perasaan senang akibat nikotin disebabkan oleh stimulasi pelepasan dopamin sehingga rasa ingin merokok akan muncul ketika kadar nikotin darah menurun. Kebiasaan merokok yang berkelanjutan akan meningkatkan risiko penyakit pada paru-paru yang yang memiliki peran penting pada sistem pernapasan.

Variabel derajat merokok dan gejala gangguan sistem pernapasan dianalisis secara bivariat menggunakan uji fisher's exact karena asumsi uji chi square tidak terpenuhi, yaitu terdapat $>20 \%$ sel dengan nilai $<5$. Sel untuk kategori perokok sedang dan berat disatukan untuk memenuhi salah satu syarat uji chi square, yaitu tidak terdapat sel yang bernilai 0 . Hasil analisis hubungan derajat merokok dengan gejala gangguan sistem pernapasan pada pegawai Unisba ditampilkan pada tabel 2.

Tabel 2. Hubungan Derajat Merokok dengan Gejala Gangguan Sistem Pernapasan pada Pegawai Unisba

\begin{tabular}{|c|c|c|c|c|c|c|c|}
\hline \multirow{3}{*}{ Derajat Merokok } & \multicolumn{4}{|c|}{$\begin{array}{c}\text { Gejala Gangguan Sistem } \\
\text { Pernapasan }\end{array}$} & \multirow{2}{*}{\multicolumn{2}{|c|}{ Total }} & \multirow{3}{*}{ p-value } \\
\hline & \multicolumn{2}{|c|}{ Normal } & \multicolumn{2}{|c|}{ Abnormal } & & & \\
\hline & $\mathbf{N}$ & $\%$ & $\mathbf{N}$ & $\%$ & $\mathbf{N}$ & $\%$ & \\
\hline Tidak merokok & 10 & $62,5 \%$ & 34 & $56 \%$ & 44 & $57 \%$ & \\
\hline $\begin{array}{l}\text { Perokok ringan } \\
(0-199)\end{array}$ & 4 & $25 \%$ & 19 & $31 \%$ & 23 & $30 \%$ & \\
\hline $\begin{array}{l}\text { Perokok sedang } \\
(200-599) / \text { Perokok } \\
\text { berat }(\geq 600)\end{array}$ & 2 & $12,5 \%$ & 8 & $13 \%$ & 10 & $13 \%$ & $0,9<1$ \\
\hline Total & 16 & $100 \%$ & 61 & $100 \%$ & 77 & $100 \%$ & \\
\hline
\end{tabular}

Sumber: Data Penelitian yang Sudah Diolah, 2020

Tabel 2 menunjukkan bahwa nilai p sebesar 0,921. Nilai p pada penelitian ini bernilai lebih besar dari $0,05(\mathrm{p}>0,05)$ sehingga dapat disimpulkan bahwa tidak terdapat hubungan yang signifikan secara statistik antara derajat merokok dan gejala gangguan sistem pernapasan pada pegawai Unisba. 
Hasil penelitian ini sesuai dengan penelitian Aryaningsih dkk. Pada petugas penyapu jalan di area Kendal Kota dan penelitian Simbolon dkk. Pada pemulung di Tempat Pembuangan Akhir (TPA) Ganet bahwa tidak terdapat hubungan yang bermakna antara kebiasaan merokok dengan timbulnya keluhan gangguan pernapasan. Begitu juga dengan penelitian yang dilakukan Zainaldi yang menyatakan bahwa tidak terdapat hubungan antara perilaku merokok dengan keluhan pernapasan pada mahasiswa Universitas Pembangunan Nasional Veteran Jakarta (UPNVJ) tahun 2020 (nilai $\mathrm{p}=1,000$ ).

Hasil penelitian yang berlawanan ditemukan pada penelitian Utami dkk. Yang menyatakan bahwa terdapat hubungan yang signifikan antara kebiasaan merokok dengan gangguan pernapasan pada 35 pekerja gudang semen Tiga Roda Bengkulu dengan nilai $\mathrm{P}=0,001$. Perbedaan hasil juga ditemukan pada penelitian Fentiana dan Putri pada 124 polisi lalu lintas serta penelitian Hidayati dan Suherman pada 106 pekerja mebel yang menyatakan bahwa kebiasaan merokok memiliki hubungan yang bermakna dengan keluhan gangguan saluran pernapasan.

Perbedaan pada penelitian ini dengan penelitian-penelitian terdahulu mengenai keluhan gangguan pernapasan dapat disebabkan oleh beberapa faktor yang dapat memengaruhi fungsi paru. Faktor-faktor yang dapat memengaruhi fungsi paru adalah paparan rokok secara pasif dan riwayat merokok. Faktor lain yang dapat berpengaruh adalah perbedaan usia, keberadaan riwayat penyakit pernapasan, status gizi, kebiasaan olahraga, dan paparan debu. Faktor-faktor lain yang dapat memengaruhi fungsi paru bukan merupakan fokus penelitian sehingga perlu dilakukan penelitian lebih lanjut terkait faktor-faktor tersebut.

Faktor lain dalam penelitian yang dapat menyebabkan hasil penelitian menjadi tidak signifikan adalah jumlah sampel, metode pengumpulan data, dan metode penilaian variabel. Jumlah sampel pada penelitian ini lebih kecil daripada perencanaan sehingga dapat meningkatkan kesalahan duga dan hasil penelitian menjadi tidak signifikan. Data jumlah rokok yang dihisap per hari dan lama merokok dikumpulkan menggunakan formulir isian yang diisi sendiri oleh responden sehingga hasil penelitian bergantung pada kejujuran dan ingatan responden penelitian (recall bias). Recall bias dapat memungkinkan data tidak sesuai dengan keadaan sebenarnya dan menjadi keterbatasan penelitian. Penilaian gangguan sistem pernapasan berdasarkan gejala yang dirasakan responden saat pengambilan data dan bersifat subjektif sehingga memungkinkan terdapat ketidaksesuaian antara apa yang dikeluhkan responden dengan kondisi yang sebenarnya.

\section{Kesimpulan}

Berdasarkan hasil penelitian dan pembahasan dalam penelitian ini, dapat disimpulkan bahwa tidak terdapat hubungan antara derajat merokok dengan gejala gangguan sistem pernapasan pada pegawai Unisba.

\section{Acknowledge}

Penulis ucapkan terima kasih banyak kepada Fakultas Kedokteran Universitas Islam Bandung dan tim penelitian yang telah mendukung dan membantu dalam penulisan artikel ini serta kepada seluruh pegawai Unisba yang telah bersedia meluangkan waktu untuk menjadi responden dalam penelitian ini.

\section{Daftar Pustaka}

[1] Suryantisa I. Situasi Umum Konsumsi Tembakau di Indonesia. Jakarta Selatan: Pusat Data dan Informasi Kementerian Kesehatan RI; 2018. hlm. 1-10.

[2] Wang R, Jiang Y, Li X, Zhao Q, Zhu M, Guan Y, dkk. Relationships Between Smoking Duration, Smoking Intensity, Hypothetical Tobacco Price Increases, and Smoking Habit Change Intention Among Current Smokers in Shanghai. J Int Med Res. 2019;47(10):5216-28.

[3] Sundari R, Widjaya DS, Nugraha A. Lama Merokok dan Jumlah Konsumsi Rokok terhadap Trombosit pada Laki-Laki Perokok Aktif. Kesmas Natl Public Heal J. 2015 Feb;9(3):257-63. 
[4] Sari SM, Afandi D, Fauzi ZA. Gambaran Perilaku Merokok Guru di Lingkungan Sekolah Menengah Pertama di Pekanbaru. J Online Mhs Fak Kedokt Univ Riau. 2015 Feb;2(1):1-12.

[5] Badan Penelitian dan Pengembangan Kesehatan. Laporan Nasional Riskesdas 2018. Jakarta: Lembaga Penerbit Badan Penelitian dan Pengembangan Kesehatan; 2019. hlm. 320-3.

[6] Saminan. Efek Perilaku Merokok terhadap Saluran Pernapasan. J Kedokt Syiah Kuala. 2016;16(3):191-4.

[7] Fentiana N, Putri RR. Kedisiplinan Penggunaan APD (Alat Pelindung Diri) pada Polantas dan Hubungannya dengan Gangguan Pernapasan. J Kesehat. 2018;11(2):107-14.

[8] Wisman BA, Mardhiyah R, Tenda ED. Pendekatan Diagnostik dan Tatalaksana Penyakit Paru Obstruktif Kronik GOLD D: Sebuah Laporan Kasus. Indones J Chest. 2015;2(4):180-90.

[9] Lianzi I, Pitaloka E. Hubungan Pengetahuan tentang Rokok dan Perilaku Merokok pada Staf Administrasi Universitas Esa Unggul. Inohim. 2014 Jun;2(1):67-81.

[10] Jayes L, Haslam PL, Gratziou CG, Powell P, Britton J, Vardavas C, dkk. SmokeHaz: Systematic Reviews and Meta-analyses of the Effects of Smoking on Respiratory Health. Chest. 2016 Jul;150(1):164-79.

[11] Cassidy RN, Roberts ME, Colby SM. Validation of a Respiratory Symptom Questionnaire in Adolescent Smokers. Tob Regul Sci. 2015 Jul;1(2):121-8.

[12] Dwicahyo HB. Analisis Kadar NH3, Karakteristik Individu dan Keluhan Pernapasan Pemulung di TPA Sampah Benowo dan Bukan Pemulung di Sekitar TPA Sampah Benowo Surabaya. J Kesehat Lingkung. 2017 Jul 2;9(2):135-44.

[13] Liu Y, Pleasants RA, Croft JB, Wheaton AG, Heidari K, Malarcher AM, dkk. Smoking Duration, Respiratory Symptoms, and COPD in Adults Aged $\geq 45$ Years with a Smoking History. Int J COPD. 2015 Jul 21;10:1409-16.

[14] Fatonah S, Amatiria G. Kepatuhan Warga terhadap Peraturan Kawasan Tanpa Rokok di Lampung Selatan. J Keperawatan. 2016 Apr;12(1):149-54.

[15] Mulyawati YN, Suherman M. Upaya Universitas Islam Bandung dalam Mensosialisasikan Kampus Bebas Asap Rokok. Pros Hub Masy; 2019;5(2):306-13.

[16] Putra AF, Sutadipura N, Yulianto FA. Hubungan Jumlah Rokok dan Lama Kebiasaan Merokok terhadap Fungsi Paru Karyawan yang Merokok di Universitas Islam Bandung. Pros Pendidik Dr. 2017;3(2):486-92.

[17] Amelia R, Nasrul E, Basyar M. Hubungan Derajat Merokok Berdasarkan Indeks Brinkman dengan Kadar Hemoglobin. J Kesehat Andalas. 2016;5(3):619-24.

[18] Alnawaiseh N, Rawashdeh A, Salahat S, Ajarmeh S. Respiratory Symptoms, Knowledge and Attitude among Male Smoker Students in Mutah University, Jordan. Biomed Pharmacol J. 2018;11(4):1947-53.

[19] Herdiana D, Uyainah A, Nugroho P, Tarigan TJE, Amin Z. Hubungan Perilaku Merokok dengan Gambaran Faal Paru pada Jemaah Haji. Indones J Chest. 2015;2(3):99-102.

[20] Aryaningsih S, Kawi, Muliawati R, Widjasena B. Faktor Risiko Keluhan Subyektif Gangguan Pernapasan pada Petugas Penyapu Jalan. J Ilm Permas. 2020;10(1):109-14.

[21] Simbolon VA, Nurmaini, Hasan W. Pengaruh Pajanan Gas Hidrogen Sulfida (H2S) terhadap Keluhan Saluran Pernafasan pada Pemulung di Tempat Pembuangan Akhir (TPA) Ganet Kota Tanjungpinang Tahun 2018. J Kesehat Lingkung Indones. 2019;18(1):429.

[22] Zainaldi M. Hubungan antara Aktivitas Berkendara Sepeda Motor dan Keluhan Pernapasan pada Mahasiswa Universitas Pembangunan Nasional Veteran Jakarta Tahun 2020. Semin Nas Kesehat Masy 2020. 2020;263-72.

[23] Utami S, Mulyati S, Noeraini NH. Kebiasaan Merokok, Penggunaan APD, dan Gangguan Pernapasan Pekerja Gudang Semen Tiga Roda Bengkulu. J Media Kesehat. 2017;10(1):25-30.

JRK is licensed under Creative Commons Attribution-

NonCommercial-ShareAlike 4.0 International License. Kedokteran 
106 | Aliya Salsabila, et al.

[24] Hidayati NH, Suherman. Hubungan Karakteristik Pekerja dengan Gejala Respiratorik Gangguan Saluran Pernapasan karena Debu Kayu pada Pekerja Mebel Sektor Informal di Kecamatan "X" - Bogor Tahun 2018. Environ Occup Heal Saf J. 2018;1(1):39-50.

[25] Rismandha R, Disrinima AM, Dewi TU. Analisis Pengaruh Faktor-Faktor Risiko Gangguan Fungsi Paru pada Pekerja Area Produksi Industri Kayu. Semin Nas K3 PPNS 2017. 2018;1(1):199-204.

[26] Husna A, Suryana B. Metodologi Penelitian dan Statistik. Kementerian Kesehatan Republik Indonesia; 2017.

[27] Syafa'ah I, Winariani. Hubungan antara Kadar IFN- $\gamma$ Sputum dan Derajat Merokok pada Pasien TB Paru BTA Positif. J Respir Indo. 2017;37(3):199-207.

[28] Cox AP, Ray PL, Jensen M, Diehl AD. Defining 'Sign' and 'Symptom.' Int Conf Biomed Ontol. 2013;42-8. 